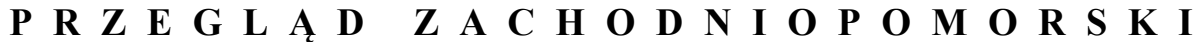 ROCZNIK XXXIII (LXII) ROK 2018 ZESZYT 3
}

\author{
Renata GaŁaj-DempniaK \\ Uniwersytet Szczeciński, Wydział Humanistyczny \\ e-mail:renata_galaj@wp.pl
}

\section{AWARIE ELEKTROWNI ATOMOWYCH - WPEYW NA INFRASTRUKTURE KRYTYCZNA \\ I ŻYCIE SPOLECZEŃSTW EUROPEJSKICH \\ na przykzadzie wypadków w Fukushimie, Czarnobylu i Tihange (W KONTEKŚCIE ODDZIALYWANIA INFORMACJI MEDIALNEJ)}

Słowa kluczowe: elektrownie jądrowe, Europa, zagrożenie wybuchem, atak terrorystyczny Keywords: nuclear power plants (NPPs), Europe, the risk of explosion, terrorist attack

Są wydarzenia, które zmieniają spojrzenie naukowców, wojskowych, a także społeczeństw na stabilność i bezpieczeństwo świata, otoczenia i własnego życia ${ }^{1}$. Do takich niewątpliwie należą wybuch w elektrowni w Czarnobylu ${ }^{2}$ czy awarie w elektrowni atomowej w Tihange.

\footnotetext{
${ }^{1}$ Strahlende Zukunft für Europas Osten, https://www.mdr.de/heute-im-osten/kernkraft-osteuropa-100.html; Niemieckie elektrownie atomowe maja być czynne tylko do 2022 roku, http:// www.dziennikzachodni.pl/artykul/409949, niemieckie-elektrownie-atomowe-maja-byc-czynne-tylko-do-2022-roku,id,t.html; R. Zasuń, B. Wieliński, Niemcy do 2021 r. wytacza elektrownie atomowe, http://wyborcza.pl/1,155287,9696034,Niemcy_do_2021_r_wylacza_elektrownie_atomowe.html?disableRedirects $=$ true.

${ }^{2}$ „Skala i konsekwencje awarii w Czarnobylu nie były przewidziane i zaskoczyły władze odpowiedzialne za zdrowie i bezpieczeństwo publiczne. Kryteria i procedury interwencyjne istniejące w większości krajów nie nadawały się do opanowania awarii o takich rozmiarach i nie pomagały w wyborze i wprowadzeniu działań interwencyjnych. Ponadto w początkowej fazie awarii mało było informacji o rzeczywistym stanie rzeczy, a decydenci musieli podejmować decyzje pod naciskiem czynników politycznych, częściowo uzasadnionych społecznym przeświadczeniem o skali
} 
11 marca 2011 roku wielkie trzęsienie ziemi i następujące po nim tsunami dokonało spustoszeń na wybrzeżu Japonii. Jednym ze skutków była awaria elektrowni jądrowej w Fukushimie. Wydarzenie to porównywane jest przez media zarówno do tragedii, do jakich doszło w Hiroszimie, jak i Czarnobylu³. Stało się współczesną ikoną zagłady, śmierci i zagrożenia. Wstrząsnęło praktycznie całym światem, który w mniej lub bardziej histeryczny sposób starał się na własną rękę bronić swoich obywateli przed skutkami promieniowania. Strach powoli odchodzi w zapomnienie, ale pozostały pytania, na które nie zawsze potrafiono dać satysfakcjonującą odpowiedź, jak choćby o skutki przyjmowania małych dawek promieniowania przez długi czas. Do przeciętnego człowieka informacje docierają obecnie przede wszystkim za pośrednictwem mediów. Powstaje literatura edukacyjna dla dzieci, która podaje podstawowe informacje o zagrożeniu nuklearnym ${ }^{4}$. Zadaje się także pytania, czy naprawdę jesteśmy przygotowani na podobne zdarzenia.

awarii" - A. Strupczewski, Skutki zdrowotne awarii w Czarnobylu, http://atom.edu.pl/index.php/ bezpieczenstwo/prawda-o-czarnobylu/skutki-zdrowotne.html.

${ }^{3}$ The Fukushima Daiichi Nuclear Accident: Final Report of the AESJ Investigation Committee, Atomic Energy Society of Japan, Springer 2014; A. Glogg, Keine Angst vor Fukushima?, Bichwil 2012; E. Ochiai, Hiroshima to Fukushima: Biohazards of Radiation, Springer 2014; R. Hindmarsh, Nuclear Disaster at Fukushima Daiichi: Social, Political and Environmental Iussues, New York 2013; G. Mackenthun, Fukushima, Norderstedt 2014; Reflections on the Fukushima Daiichi Nuclear Accident. Toward Social-Scientific Literacy and Engineering Resilience, red. J. Ahn, C. Carson, M. Jensen, K. Juraku, S. Nagasaki, S. Tanaka, Springer 2015; F. Coulmas, J. Stalpers, Fukushima. Vom Erdbeben zu atomaren Katastrophe, München 2011; Y. Hatamura, S. Abe, M. Fuchigami, N. Kasahara, The 2011 Fukushima Nuclear Power Plant Accident, Elsevier 2014. Prace krytykujące elektrownie jądrowe: T. Hirose, Fukushima Meltdown: The World's First Earthquake-Tsunami-Nuclear Disaster, Createspace 2012; D. Elliott, Fukushima: Impacts and Implications, Palgrave Pivot 2012; P.B. Ladkin, Ch. Goeker, B. Sieker, The Fukushima Dai-Ichi Accident, LIT Verlag 2013; Radiation Monitoring and Dose Estimation of the Fukushima Nuclear Accident, red. S. Takahashi, Springer 2014; The Fukushima Daiichi Nuclear Power Station Disaster: Investigating the Myth and Reality, red. M.K. Bricker, London 2014; T.M. Nakanishi, K. Tanoi, Agricultural Implications of the Fukushima Nuclear Accident, Springer 2013; H. Caldicott, Crisis without End: The Medical and Ecological Consequences of the Fukushima Nuclear Catastrophe, New York 2014; P. Povinec, K. Hirose, M. Aoyama, Fukushima Accident: Radioactivity Impact on the Environment, Elsevier 2013; M.H. Nadesan, Fukushima and the Privatization of Risk, Palgrave Pivot, 2013; P. Bacon, Ch. Hobson, Human Security and Japan's Triple Disaster. Responding to the 2011 Earthquake, Tsunami and Fukushima Nuclear Crisis, Abington-New York 2014; S. Boos, Fukushima lässt grüßen, Zürich 2012; K. Roberson, Silence Deafening, Fukushima Fallout... a Mother's Response, North Charleston 2013; Ch. Hubbard, Fukushima and Beyond: Nuclear Power in a Low-Carbon World, Farnham 2014.

${ }^{4}$ P.M. Moran, The Sushi-Eating Basset Hound from Fukushima Japan, North Charleston, SC 2013. 
Bez wątpienia ani organizacje zajmujące się energią jądrową, ani elektrownie i narody nie były przygotowane na rozmiar katastrofy, jej skutki i konieczność improwizacji. Wydawało się, że dotychczasowe zdarzenia, zwłaszcza awaria elektrowni w Czarnobylu, przygotowały zarówno służby do podejmowania działań w razie zagrożenia, jak i podstawy prawne do ewentualnego zwalczania skutków promieniowania. Dzień 11 marca 2011 roku zweryfikował to przekonanie. Uświadomił, że zjawiska natury i przyroda mogą nakreślić scenariusz, którego człowiek nie przewidzi i nie opanuje. Zresztą do dzisiaj uczymy się zachowywania właściwego dystansu i postawy wobec natury i energii jądrowej5.

Czego nauczyły nas awarie elektrowni i przypadki tsunami? Że nadal zbyt wiele osób, nawet pozostających na rządowych posadach, nie docenia mocy wymienionych wydarzeń, zjawisk, cóż dopiero mówić o zwykłych ludziach. Także tego, że potrzeby energetyczne w Europie i na świecie są tak wielkie, że trudno jest z dnia na dzień zrezygnować z tego źródła energii. Rządy muszą przygotować alternatywne źródła jej pozyskiwania i uwzględnić bardziej niż dotychczas zmiany pogodowe i klimatyczne wywołujące nagłe zjawiska w postaci wysokich fal, trąb powietrznych, huraganów itp., również na terenach nienawiedzanych dotąd przez podobne zjawiska.

Tsunami, będące sprawcami wielu tragedii, zostało wielokrotnie zlekceważone, mimo że wiedziano o nadchodzącym zjawisku dzięki systemowi wczesnego ostrzegania ${ }^{6}$. W konsekwencji zginęli ludzie. Stacje sejsmologiczne i pomiarowe wyposażone są w instrumenty pomiarowe rejestrujące wstrząsy i ruchy tektonicznie, zachowanie wód morskich, prądów oceanicznych, co pozwala przez całą dobę obserwować sytuację na lądzie i oceanie. Obecnie naukowcy są w stanie przewidzieć, w jakim kierunku, z jaką siłą i w jakim czasie będą rozprzestrzeniały się fale tsunami. Można zadać sobie pytanie: dlaczego więc wciąż giną ludzie? Dlaczego Japonia w marcu 2011 roku nie ewakuowała ludzi z terenów zagrożonych przez tsunami? Państwo to ma odpowiednie służby, ale - jak w wielu krajach - zebrane przez ludzi „doświadczenia życiowe” wzięły górę nad zdrowym rozsądkiem. Największym problemem Japonii po tsunami była awaria elektrowni jądrowej. Teoretycznie posiadano wypracowane procedury reagowania w sytuacji kryzysowej, jednak nie przewidziano kompletnego zniszczenia

\footnotetext{
${ }^{5}$ Lista ujawnionych awarii elektrowni jądrowych na świecie (do 2009 r.), https://sites.google. com/site/awarielektrowni.

${ }^{6}$ P. Symonds, The Asian Tsunami: Why There Were No Warnings, http://www.wsws.org/en/ articles/2005/01/warn-j03.html.
} 
infrastruktury niezbędnej do prowadzenia akcji ratunkowej. Zbiurokratyzowanie procedur odbiło się na tempie podejmowanych działań. Okazało się, że zniszczenie dróg, linii kolejowych, lotnisk uniemożliwiło udzielenie pomocy, a straż przybrzeżna nie miała prawnej możliwości współpracy z ekipami ratowników, chociaż do wielu miejsc można było dotrzeć tylko wodą. Poświęcenie ludzi, determinacja Czerwonego Krzyża i innych organizacji, pomoc osób prywatnych pozwoliły w początkowym okresie opanować sytuację. Rząd musiał dokonać zmian prawnych, aby umożliwić służbom działanie w nieprzewidzianych wcześniej warunkach. Pracowano najszybciej jak można, ale dla wielu ludzi pomoc przyszła za późno. Na bieżąco trzeba było rozwiązywać problemy, z którymi wcześniej nie miano do czynienia - np. co zrobić ze skażoną wodą ze zbiorników elektrowni, gdyż zbiorniki były niezbędne przy dalszej akcji ratowniczej.

W innych państwach azjatyckich narażonych na podobne zjawiska również pracują elektrownie jądrowe. Ich stan techniczny, podobnie jak wielu europejskich obiektów, budzi obawy, a wydarzenia w Fukushimie uświadomiły społeczeństwom i rządom, że skali kataklizmów i ich skutków w kontekście pracy elektrowni nie da się przewidzieć. Takie obawy dotyczą również innych obiektów, jak choćby zakładów, w których używa się chemikaliów. W wielu uboższych państwach z powodu zacofania technologicznego brakuje odpowiedniej infrastruktury, a urzędnikom - umiejętności odczytywania przesyłanych ze stacji sygnałów (z sejsmometrów, tsunamometrów).

Społeczeństwo Japonii i terenów narażonych na erupcje wulkaniczne czy ruchy tektoniczne świadome jest konsekwencji np. wybuchu wulkanów czy trzęsień ziemi. Jednak, jak wskazuje dokumentacja zgromadzona po awarii w Fukushimie, nawet tam ludzie potrafią zachować się w sposób nieprzewidywalny dla służb, kierując się tzw. doświadczeniem życiowym, a nie poleceniami płynącymi $\mathrm{z}$ radia, telewizji czy bezpośrednio od przedstawicieli służb ratowniczych. Uzmysławia ten problem zachowanie ludzi, którzy, nie zdając sobie sprawy z niszczycielskiej siły tsunami, po pierwszym uderzeniu fali i cofnięciu się wód wracali na brzeg popatrzeć, co się wydarzyło, lub po promieniowaniu (którego przecież nie widać) wracali do domów na skażonym terenie, by doglądać dobytku. Także władze lokalne innych państw, nie chcąc wywoływać paniki, zwłaszcza na obszarach Azji, czerpiących dochody z turystyki, nie wszczynają „pochopnie” 
alarmu, co często przekłada się na straty w ludziach? ${ }^{7}$ W tym ostatnim wypadku informacje o zagrożeniu nie docierały do mediów, nie były więc nagłaśniane. Po awarii elektrowni w Fukushimie za jedno z priorytetowych działań uznano uruchomienie łączności medialnej z poszkodowanymi ludźmi, aby tą drogą koordynować akcję ratunkową. Wszystkie japońskie media prowadziły relację w czasie realnym. Zaprzestano nawet prowadzonej cyfryzacji, bowiem nie wszyscy obywatele mieli odbiorniki inne niż analogowe. Wśród dostarczanego poszkodowanym sprzętu znalazły się radia. Ważną rolę odegrał także Internet i telefony komórkowe. Za ich pośrednictwem informacje docierały także do pozostałych państw świata. Wiele stacji tłumaczyło na bieżąco informacje nadchodzące z Japonii na język narodowy.

Awaria elektrowni w Fukushimie i tsunami sprowadziły realne zagrożenie dla infrastruktury krytycznej więcej niż jednego narodu, podobnie jak wcześniejsza awaria elektrowni w Czarnobylu. Ludzie w części Japonii odcięci zostali od wody pitnej, żywności, prądu, gazu. Media japońskie starały się uspokajać i hamować objawy paniki. Okazało się, że ratunek nie przyjdzie ani z wody, ani z powietrza, bo nie przewidziano takiej skali zniszczenia infrastruktury komunikacyjnej, do jakiej doszło. Pozostawał tylko człowiek, który z narażeniem życia docierał tam, gdzie oczekiwano na pomoc. Człowiek pozbawiony początkowo odpowiedniego zabezpieczenia, gdyż zabrakło właściwej odzieży i mierników stopnia promieniowania. Nie przewidziano, że ryby, ptaki i zwierzęta będą przenosiły skażenie radioaktywne na obszary dalekie od miejsca awarii, że ludzi uspokoją „doświadczenia życiowe” i nie zachowają czujności ${ }^{8}$. Powstało pytanie, co zrobić ze skażoną wodą z elektrowni, która ze zbiorników trafiła ostatecznie do oceanu, bowiem trzeba było przygotować miejsce na jej bardziej skażoną część. Wywołało to panikę, nerwowe reakcje innych państw, groźby oddania sprawy do Trybunału Międzynarodowego. Nie istniały jednak żadne przepisy prawne mówiące,

\footnotetext{
${ }^{7}$ J. Giles, E. Marris, Indonesian Tsunami-monitoring System Lacked Basic Equipment, http:// www.nature.com/news/2004/041229/full/news041229-4.html; M. Ochwat, Niszczycielska moc tsunami. Analiza wybranych aspektów tsunami w latach 20004 i 2011, w: Międzynarodowe implikacje awarii elektrowni atomowej w Fukushimie. Wybrane aspekty problemu, red. R. Gałaj-Dempniak, Szczecin 2015, s. 33.

${ }^{8}$ Fukushima Nuclear Disaster: Former Tepco Executives go on Trial, https://www.theguardian.com/environment/2017/jun/30/fukushima-nuclear-crisis-tepco-criminal-trial-japan; Fukushima Evacuee to Tell UN that Japan Violated Human Rights, https://www.theguardian.com/environment/2017/oct/11/fukushima-evacuee-un-japan-human-rights; Japanese Government Held Liable for First Time for Negligence in Fukushima, https://www.theguardian.com/world/2017/mar/17/ japanese-government-liable-negligence-fukushima-daiichi-nuclear-disaster.
} 
jak w podobnej sytuacji należy postąpić. Okazało się, że tak naprawdę nie ma wypracowanych ani podstaw prawnych, ani zasad postępowania w obliczu tak druzgocącej katastrofy, bowiem nigdy wcześniej nie doszło do kataklizmu na tak wielką skalę9. Problemem była przewlekłość działań systemu reagowania, nieadekwatna do powstałej sytuacji i dynamiki wydarzeń, oraz rozległość obszaru. Kolejne państwa ewakuowały swoich obywateli z Japonii, zamykały granice dla japońskich produktów. Niektóre na tragedii kraju postanowiły umocnić własną gospodarkę, wchodząc na rynki w lukę powstałą po japońskich towarach. Nawet $\mathrm{w}$ Europie organizacje konsumenckie straciły zimną krew. Kontrolowano wszystkie importowane produkty, a każda podejrzana czy wykryta skażona partia towaru nakręcała spiralę strachu. System kontroli okazał się jednak bardzo skuteczny, a skażenie, rozprzestrzeniające się przez będące w stałym ruchu wodę czy powietrze, nie zagroziło życiu na kontynencie europejskim. Agencje rządowe prowadziły stały monitoring, a jego wyniki publikowano w Internecie ${ }^{10}$, każdy zainteresowany mógł więc do nich dotrzeć. Takie działania podjęły również wyspecjalizowane agendy ONZ. Jednak doświadczenia z Czarnobyla odcisnęły piętno na sposobie rozumowania Europejczyków. Pomimo dostępu do informacji nie dowierzano ich treści. Doszukiwano się celowego pomniejszania konsekwencji w przekazywanych informacjach, które zdaniem niektórych miały na celu jedynie uspokojenie ludzi - świadczą o tym powstające liczne blogi czy strony internetowe, podważające szczerość intencji rządów i organizacji ${ }^{11}$.

Kolejne zagrożenie dla spokoju społecznego wynikało z braku powszechnego dostępu do wyników badań nad konsekwencjami długotrwałego oddziaływania niskich dawek promieniowania na żywe organizmy i wiedzy co do ich dalekosiężnych skutków. Badania po Czarnobylu przyniosły wiedzę odnośnie do

\footnotetext{
${ }^{9}$ Interesująca jest praca Richarda Lloyda Parry'ego, Ghosts of the Tsunami: Death and Life in Japan's Disaster Zone, London 2017. Największą jej wartość stanowią przeżycia i przemyślenia poszkodowanych.

${ }^{10}$ Fukushima Daiichi Status Updates, IAEA, https://www.iaea.org/newscenter/focus/ fukushima/status-update.

${ }^{11}$ Np. Project Food NPO, http://project-food.jimdo.com (działał w latach 2013-2015, kiedy strach przed napromieniowaniem był wszechobecny); Network of Parents to Protect Children from Radiation (Mamorukai), http://kodomozenkoku.com/network.html; Seikatsu Club, https:// www.rightlivelihoodaward.org/laureates/seikatsu-club-consumers-cooperative/; Food Safety News, https://www.foodsafetynews.com/tag/japan/; Food Safety Japan 2018, http://www.f-sys. info/fsj/english/. Obecnie działa także Food Safety Information, https://www.mhlw.go.jp/english/ topics/foodsafety/, która broni japońskiej żywności i wyjaśnia, jak postępować np. w przypadku wykrycia skażonych produktów.
} 
długofalowych skutków krótkotrwałego, silnego napromieniowania, i to także częściową. Panika, która wówczas wybuchła, dotyczyła: skażenia żywności i wody dla ludzi i zwierząt, skutków dla zdrowia i możliwości chronienia ludzi i zwierząt, zdziczałych zwierząt domowych i dzikich zwierząt (ryb, ptaków, lisów, jeleni itp.) przemieszczających się po strefie skażonej i opuszczających teren zamknięty z powodu skażenia, oddziaływania ziemi i tamtejszych roślin na organizmy ludzi i zwierząt, miejsc, z których stale, pomimo upływu lat, wydobywa się skażona woda, i mutacji zwierząt (jak donosiły media). Problemy i pytania poruszane przez ludzi po awarii w Fukushimie przypominały więc pytania o konsekwencje, które pociągnęła za sobą katastrofa w Czarnobylu.

Zmusiło to rządy do podjęcia kroków w sprawach: gromadzenia, opracowywania i udostępniania danych dotyczących Fukushimy, ale i innych podobnych zajść; wypracowania systemu sprawniejszego niesienia pomocy i usuwania przyczyn katastrof we wszystkich państwach korzystających z energii jądrowej; sprawdzania sprawności reaktorów i realnego zagrożenia, które stwarzają w krytycznych warunkach (tzw. testy krytyczne); konieczności wypracowania zasad ściślejszej międzynarodowej współpracy w obliczu tego typu zagrożeń, gdyż niekiedy przekraczają one granice i możliwości reagowania jednego kraju; wypełnienia ujawnionych istniejących luk prawnych dotyczących przeciwdziałania tego typu zagrożeniom. O wybranych aspektach awarii w Fukushimie i jej skutkach powstały już prace analityczne ${ }^{12}$. Naukowcy pochylali się nad wieloma problemami w trakcie konferencji, kongresów czy warsztatów.

Zdaniem Andrew DeWita doświadczenia wyniesione z katastrofy uczyniły z Japonii nie tylko symbol porażki człowieka wobec żywiołu, ale i maszynę napędową przemian mających zapewnić bezpieczeństwo w obszarach krytycznych: energetyce, żywności, wodzie, transporcie ${ }^{13}$. Prace prowadzone przez to państwo znacznie wyprzedzają w tym zakresie Amerykę Północną, UE czy inne kraje azjatyckie. Od 2013 roku wydatki Japonii na wzrost odporności i stabilność

\footnotetext{
12 Jedna powstała pod redakcją autorki: Międzynarodowe implikacje awarii elektrowni atomowej w Fukushimie. Wybrane aspekty problemu, red. R. Gałaj-Dempniak, Szczecin 2015.

13 „But in point of fact, 3-11 has made Japan a world leader in building resilience - in critical energy, water, transport and other lifeline infrastructures - against increasingly frequent disasters confronting Japan, the Asia-Pacific and the world. Though little known, even in specialist circles, Japan's deeply institutionalized and well-funded programme of »National Resilience« (kokudokyoujinka) is far more advanced than its counterpart initiatives in North America, the EU and elsewhere” - A. DeWit, Japan's „,National Resilience” and the Legacy of 3-11, „The Asia-Pacific Journal" 2016, Vol. 14 (6), No. 1, https://apjjf.org/-Andrew-DeWit/4870/article.pdf.
} 
infrastruktury krytycznej rosną, ale zasadniczy wzrost ma przynieść rok $2020^{14}$. Cabinet Secretariat's National Resilience Council, Association for Resilience Ja$\operatorname{pan}^{15}$ i podmioty współpracujące kładą nacisk zwłaszcza na kwestie związane z energetyką - dywersyfikację źródeł pozyskiwanej energii. Uznano, że należy zużywać więcej energii produkowanej ze źródeł odnawialnych (energia słoneczna, wiatrowa). Zwiększenie popytu ma przynieść np. wprowadzenie pojazdów elektrycznych czy wzmocnienie tych sektorów przemysłu, które są bardzo energochłonne. Sektor energetyczny powiązany jest z innymi rynkami. Jeśli nie wzrośnie zapotrzebowanie na energię w motoryzacji i gospodarce, to ta bezpieczna, pochodząca ze źródeł odnawialnych, przy zbyt małej liczbie odbiorców i usług, będzie za droga. To zresztą zadecydowało o wycofaniu się rządu Shinze Abe z pierwotnego pomysłu, powstałego w okresie po awarii, całkowitego zrezygnowania z wytwarzania energii atomowej. Budowa sektora energetycznego od podstaw była zbyt kosztowna dla państwa, które do dzisiaj nie uporało się ze skutkami awarii i tsunami w kwestiach przede wszystkim infrastruktury i społecznych. Wydarzenia w Fukushimie wywołały dyskusje na temat bezpieczeństwa energetycznego w kontekście rozległości skutków awarii tego typu elektrowni. Awarie zarówno w Czarnobylu, jak i w Fukushimie wpłynęły na życie Europejczyków. Ta pierwsza w sposób bezpośredni, druga pośrednio, doprowadziła do wznowienia dyskusji na temat bezpieczeństwa tego typu elektrowni i stanu przygotowania społeczeństw na takie zagrożenie.

Skutki takich zdarzeń są nieprzewidywalne i dalekosiężne. Ryby, ptaki zwierzęta, skażone pierwiastkami promieniotwórczymi, przemieszczały się po Japonii. Podobnie stało się po wybuchu w elektrowni w Czarnobylu ze zwierzętami wód i lasów. Ludzie, łowiąc ryby, nie wiedzą, czy nie zjadły one skażonej roślinności, skorupiaka czy innej ryby. Człowiekowi stale towarzyszy więc strach i niepewność. Do dzisiaj w niektórych państwach europejskich pojawiają się skażone po awarii w Czarnobylu zwierzęta i rośliny. Media szwedzkie w październiku 2017 roku po raz kolejny zwróciły się do społeczeństwa z prośbą

\footnotetext{
14 „As we shall see below, Japan's resilience programme, including both public and private sector spending, totaled over JPY 24 trillion (USD 210 billion) in 2013 and is projected to grow dramatically by $2020 "$ - tamże.

${ }^{15}$ Krajowa Centrala Promocji Odporności, na czele której stoi premier. Posiada własny sekretariat, dyrektora generalnego, powołana w grudniu 2013 r. na podstawie Ustawy o Odporności Narodowej.
} 
o niespożywanie mięsa dzików, bo może być napromieniowane ${ }^{16}$. Odstrzelony w Gävle w środkowej Szwecji dzik miał 10-krotnie przekroczony dopuszczalny próg napromieniowania mięsa. Rodzi się zatem pytanie, czy są to dziki żyjące w Szwecji, czy przywędrowały z terenów Rosji bądź Finlandii. Dla zwierząt nie ma granic. Takich skutków, tyle lat po wybuchu, społeczności europejskie się nie spodziewały. Promieniotwórczy cez dostał się do organizmu zwierzęcia wraz z pobieranym pokarmem, tak jak w Japonii. Na 30 pobranych tylko w 2017 roku próbek z ubitych w Szwecji dzików, które badał szwedzki konsultant ds. środowiska, tylko sześć nie było skażonych ${ }^{17}$. W Szwecji istnieją dwa laboratoria mające uprawnienia do prowadzenia tego typu badań. Poza dzikami napromieniowane jest też mięso jeleni, łosi i reniferów, chociaż w ich mięsie zmniejsza się ilość promieniotwórczego pierwiastka. Oznacza to, że oczyszczają się miejsca ich żerowania; musimy stale pamiętać, że katastrofa w Czarnobylu miała miejsce 31 lat temu. Szwedzka Agencja ds. Żywności i Leków przyznała, że około 1\% żywności obecnie może być jeszcze skażony cezem; poza dziczyzną i rybami są to jagody, grzyby, niektóre kłącza i orzechy ${ }^{18}$. Dziczyzna i dary pól i lasów mogą być szkodliwe dla zdrowia, jeżeli pochodzą ze skażonych ongiś terenów: Västmanlandu, Uppsali i Gävleborga ${ }^{19}$. Natomiast kontrole, które instytucja ta prowadziła po awarii elektrowni w Fukushimie, wykazały, że nie nastąpiło podwyższone promieniowanie. Dlatego uznano, że wydarzenia 2011 roku w Japonii nie przyniosły dla Szwecji zagrożenia na skalę katastrofy w Czarnobylu z 1986

${ }^{16} \mathrm{zdr} / \mathrm{ml} /$, Rekordowo napromieniowany dzik $w$ Szwecji. 31 lat po katastrofie $w$ Czarnobylu, Polsat News, http://www.polsatnews.pl/wiadomosc/2017-10-06/napromieniowane-dziki-w-szwecji31-lat-po-katastrofie-elektrowni-jadrowej-w-czarnobylu/.

${ }^{17}$ Tamże; zob. również stronę Szwedzkiej Agencji ds. Żywności i Leków, Livsmedelsverket, https://www.livsmedelsverket.se/livsmedel-och-innehall/oonskade-amnen/radioaktivitet-ochbestralning/bestralning-av-livsmedel.

${ }^{18}$ Radioaktiva ämnen - cesium, Livsmedelsverket, https://www.livsmedelsverket.se/ livsmedel-och-innehall/oonskade-amnen/radioaktivitet-och-bestralning/radioaktiva-amnen.

${ }^{19}$ Problem ten badają i nagłaśniają: Szwedzki Uniwersytet Nauk Rolniczych, Urząd ds. Bezpieczeństwa Radiologicznego i Szwedzki Urząd ds. Bezpieczeństwa Żywności, Państwowy Urząd Weterynaryjny. Radioaktivt cesium $i$ vildsvin, Livsmedelsverket, https:// www.livsmedelsverket.se/livsmedel-och-innehall/oonskade-amnen/radioaktivitet-och-bestralning/ radioaktivt-cesium-i-vildsvin-fragor-och-svar. 
roku ${ }^{20}$. Radioaktywne jest nadal także mięso części reniferów w Norwegiii ${ }^{21}$. Holendrzy po awarii elektrowni w Czarnobylu mają złe wspomnienia - tygodnie obaw o skażenie trawy, mleka, mięsa oraz produktów, które importowano z Europy Wschodniej. Dlatego w 1989 roku ich rząd utworzył Narodowy Plan Kontroli Wypadków Nuklearnych (NPK) dla kontrolowania zachodzących zdarzeń22.

Po awarii elektrowni w okolicy Czarnobyla, jak szacują naukowcy, żyje więcej zwierząt niż przed nią ${ }^{23}$. Do mieszkańców strefy zalicza się wilki, niedźwiedzie brunatne, łosie, jelenie, bobry, dziki, żubry, dzikie konie, zające, norki, fretki, lisy, łabędzie, jastrzębie, orły, sowy, bociany, kruki i inne. Podobnie dzieje się w Japonii, gdzie niezakłócona działalnością człowieka natura stworzyła szybko doskonałe warunki dla rozwoju fauny. Wyludnienie terenu przysporzyło spokojnych, bezpiecznych miejsc dla powstania ostoi dzikiej zwierzyny. Nasuwa się pytanie, jaka jest kondycja żyjących tam stworzeń i jakie zagrożenie ewentualnie stanowią dla środowiska. W opuszczonych, pełnych żywności magazynach i sklepach zamkniętej strefy w Japonii masowo lęgną się np. gryzonie, które są elementem niepożądanym, a mogą zacząć migrować na inne obszary. Co więc robić w podobnych sytuacjach? Japończycy musieli zacząć w skażonych strefach np. odstrzał dzików, będących obecnie zagrożeniem dla ludzi. To pociąga konsekwencje w postaci znalezienia sposobu na utylizację padłych zwierząt. Jest to problem, który trzeba rozwiązać, zanim zacznie zagrażać zdrowiu ludzi.

Także kraje niemieckie i Austria mają problem ze skażonym po awarii w elektrowni w Czarnobylu środowiskiem. Opadem radioaktywnym w 1986 roku zostały mocno skażone niektóre obszary Bawarii i Badenii-Wirtembergii ${ }^{24}$.

${ }^{20}$ Wówczas skażone mocno zostały ziemie Szwecji i Norwegii - Tjernobylolyckan - lägetefter 25 år, https://www.livsmedelsverket.se/globalassets/livsmedel-innehall/oonskade-amnen/radioaktivitet/tjernobylolyckan--laget-efter-25-ar.pdf.

${ }^{21}$ Tsjernobyl: 7 gevolgenvaneen 30-jarigekernramp, http://www.knack.be/nieuws/planet-earth/ tsjernobyl-7-gevolgen-van-een-30-jarige-kernramp/article-normal-692851.html.

${ }^{22} 30$ jaar Tsjernobyl, http://www.rivm.nl/Onderwerpen/O/Ongevallen_en_rampen/Kernongevallen/30_jaar_Tsjernobyl.

${ }^{23}$ M. Ivarsson, 30 år efte rolyckan tar djuren över Tjernobyl, Allt om Resort, https://www.expressen.se/allt-om-resor/30-ar-efter-olyckan-tar-djuren-over-tjernobyl/.

${ }^{24}$ Wildschweine auch 25 Jahre nach Tschernobyl verstrahlt, Proplanta, http://m.proplanta. de/Agrar-Nachrichten/Umwelt/Wildschweine-auch-25-Jahre-nach-Tschernobyl-verstrahlt_article1300384973.html. Zob. L. Ebermann, A. Junkert, Tschernobyl - 20 Jahre Danach, Bundesamt für Strahlenschutz, www.lehrer.uni-karlsruhe.de/ za976/strlschtz/.../Tscherno20.pdf; Radioaktivität in Baden-Württemberg, Landesanstalt für Umwelt, Messungen und Naturschutz Baden-Württemberg, Karlsruhe 2012, https://www4.lubw.baden-wuerttemberg.de/.../radioaktivitaet_200. 
Jeszcze w 2014 roku Niemcy szacowali, że skutki skażonego deszczu przetrwają w postaci skażonego runa leśnego, mięsa dzików i innej zwierzyny przez następne 28 lat $^{25}$. Bawarskie Towarzystwo Łowieckie jest oskarżane przez wielu Niemców o manipulowanie danymi dotyczącymi skażenia mięsa zwierzyny łownej, zwłaszcza dzików ${ }^{26}$. Raport Federalnego Biura Ochrony Radiologicznej we wrześniu poinformował, że raport Federalnego Urzędu Ochrony Przed Promieniowaniem przestrzega,że grzyby z niektórych rejonów Bawarii nadal są nadmiernie obciążone cezem $137^{27}$. Zjadanie mięsa dzikich zwierząt i runa leśnego uznano co prawda za dopuszczalne w rozsądnych ilościach, nikt nie określił jednak, jaka ilość pożywienia może uchodzić za rozsądną.

Z radioaktywnością poczarnobylową mają problem także Czesi na południowo-zachodnich obszarach państwa. Dzika zwierzyna i leśne runo nie są bezpieczne dla konsumenta ${ }^{28}$. W Polsce skutki promieniowania po awarii w elektrowni w Czarnobylu szczególnie odczuwalne były na Śląsku. W 2011 roku próbki ziemi z lasów pod Olesnem, zbadane przez Instytut Fizyki Jądrowej Polskiej Akademii Nauk, były nadal skażone cezem ${ }^{29}$. Mieszkańcy wspominali, że docierały do nich komunikaty, że zbieranie grzybów, jagód i jeżyn w tych lasach i ich jedzenie może doprowadzić nawet do choroby nowotworowej. $Z$ biegiem lat ludzie o tym zapomnieli i nikt nie myśli obecnie o promieniowaniu, tylko korzysta z runa leśnego. Naukowcy z Wydziału Przyrodniczo-Technicznego Uniwersytetu Opolskiego opublikowali uspokajające wyniki badań, wskazujące, że jedzenie grzybów i owoców z lasów pod Olesnem nie jest już niebezpieczne dla człowieka, o ile ktoś nie spożyje w krótkim czasie czterech kilogramów suszonych grzybów pochodzących z najbardziej skażonego terenu. W 2002 roku powołano międzynarodową grupę mającą za zadanie badać skutki tej katastrofy,

2528 Jahre nach Tschernobyl: Wildschweine und Pilze strahlen weiter, http://www.n-tv.de/wissen/Wildschweine-und-Pilze-strahlen-weiter-article12721231.html.

${ }^{26}$ Geheimsache radioaktiv verstrahlte Wildsäue, „Welt”, 20.04.2015, https://www.welt.de/wissenschaft/umwelt/article139797061/Geheimsache-radioaktiv-verstrahlte-Wildsaeue.html.

${ }^{27}$ Pilze in bayerischen Wäldern nach wie vor radioaktiv verseucht, Proplanta, 27.09.2017, http://m.proplanta.de/Agrar-Nachrichten/Verbraucher/Pilze-in-bayerischen-Waeldern-nachwie-vor-radioaktiv-verseucht_article1506470529.html.

${ }^{28}$ Radioaktive Verseuchung tschechischer Wildschweine hält an, Proplanta, 19.01.2017, http://m.proplanta.de/Agrar-Nachrichten/Umwelt/Radioaktive-Verseuchung-tschechischer-Wildschweine-haelt-an_article1484837806.html.

${ }^{29}$ Lasy pod Opolem to najbardziej napromieniowane miejsce w Polsce, https://kontakt24. tvn24.pl/lasy-pod-opolem-to-najbardziej-napromieniowane-miejsce-w-polsce,81601,ugc. 
tzw. Forum Czarnobylskie. Utworzyło je: UNSCEAR, Międzynarodowa Agencja Energii Atomowej, Organizacja ds. Wyżywienia i Rolnictwa FAO, Biuro NZ ds. Koordynacji Pomocy Humanitarnej OCHA, Program NZ ds. Rozwoju UNDP, Program Środowiskowy NZ UNEP, Światowa Organizacja Zdrowia WHO, Bank Światowy oraz rządy Białorusi, Rosji i Ukrainy ${ }^{30}$.

Spożywanie skażonej żywności, podobnie jak napromieniowanie, może być przyczyną chorób, z którymi człowiek, a pośrednio rządy dotkniętych katastrofą państw, muszą walczyć, a jest to kosztowna procedura badań przesiewowych, monitorowania i zapewnienia właściwej opieki poszkodowanym. Chorobami tymi są: nowotwory, zaćma, choroby układu krążenia. Dochodzą do tego skutki traumatycznych przeżyć: depresje u dzieci (strach, moczenie się, brak skupienia, poczucie winy związane ze śmiercią bliskich, poczucie osamotnienia) i ludzi starszych (lęki po przesiedleniu, zmiana środowiska, brak bliskich i znajomych osób). Japonia po katastrofie w Fukushimie musiała zbudować cały sektor pomocowy. U wielu dorosłych i dzieci zdiagnozowano syndrom stresu pourazowego, choroby psychiczne (lęki, depresje u poszkodowanych i przesiedlanych) ${ }^{31}$. Ludzie poszkodowani boją się, prowadzi to do lęków i połączonych z nimi natręctw, braku pewności siebie, w efekcie może doprowadzić do wykluczenia społecznego, braku pracy i ubóstwa, co stanie się równie wielkim problemem. Skutki awarii w Fukushimie nie występują w Europie. Szybka reakcja rządów i organizacji konsumenckich wystraszyła społeczeństwa, jednak konsekwentna akcja informacyjna oraz informacje, do których każdy zainteresowany mógł dotrzeć, stosunkowo szybko uspokoiły emocje i pozwoliły wrócić do normalnego życia. Towary z Japonii długo jednak znajdowały się „na cenzurowanym”, a państwo to, by powrócić na rynki europejskie, zmuszone było podjąć akcję informacyjną o opanowaniu sytuacji i bezpieczeństwie japońskich produktów spożywczych.

W kontekście przytoczonych faktów zastanawiająca jest turystyka, która zrodziła się ostatnimi laty - zwiedzanie terenów wokół Czarnobyla. Ludzie zdają się zapominać o rozsądku, szukając mocnych wrażeń. Biura podróży oferują „wyjazd, którego wszyscy Twoi znajomi będą ci zazdrościć” - mocne przeżycia,

${ }^{30}$ Fakty przeciwko mitom, http://www.strefaczarnobyl.pl/fakty-przeciwko-mitom.html; UNSCEAR - Komitet Naukowego ONZ ds. Skutków Promieniowania Atomowego; A. Strupczewski, Skutki zdrowotne awarii w Czarnobylu...

${ }^{31}$ E.Rosell,30årsen Tjernobyl-sammanfattningavkonsekvensernaförmänniskorochmiljö,http:// supermiljobloggen.se/nyheter/2016/04/30-ar-sen-tjernobyl-sammanfattning-av-konsekvensernafor-manniskor-och-miljo. 
niezapomniane atrakcje ${ }^{32}$. Czarnobyl stał się więc atrakcją, ale czy z awarii elektrowni wyciągamy naukę? Czy przekłada się ta wiedza na świadomość zagrożenia niesionego przez atom i sposób działania ludzi na rzecz zminimalizowania tego zagrożenia? Nie ma na razie żadnych badań prowadzonych w tym kierunku.

Czy dawne katastrofy mogą jeszcze realnie zagrozić Europejczykom? Według niektórych naukowców pożary lasu mogą stać się przyczyną wtórnego skażenia, jeżeli uwolnią z roślin zgromadzone w nich pierwiastki promieniotwórcze, które w postaci popiołu może na duże odległości przenieść wiatr ${ }^{33}$. Taki stan podniecenia i lęku wywołał pożar lasu w pobliżu elektrowni na Ukrainie, o którym donosiły media ${ }^{34}$. Zanim wyjaśniło się, co się naprawdę stało, informacja wywołała zamieszanie, spekulacje i niepokój. We wrześniu 2017 roku, po awarii elektrowni w Tihange w Belgii, lęk wywołali Niemcy, którzy w Akwizgranie rozdali tabletki z jodem 3 tys. osób (Polsat News, Dziennik Polski24) ${ }^{35}$. Pojawiła się też w Internecie wiadomość, że po pierwszych pęknięciach w elektrowni Tihange w Belgii w kwietniu 2017 roku rząd tego państwa rozdał obywatelom $11 \mathrm{mln}$. tabletek jodu ${ }^{36}$. Taka wiedza ludzi nie uspokaja, wywołuje raczej nerwową atmosferę. Rodzą się pytania o przyczyny akcji podjętej przez rządy Niemiec czy Belgii. Czy aby polski rząd nie bagatelizuje sprawy? Przecież Belgowie, o których elektrownię chodzi, nie bez powodu rozdali najwięcej tabletek. Z prowadzonych na uczelniach badań nad rolą mediów w sytuacjach zagrożenia wynika, że mogą one odegrać w przypadku zagrożenia ogromną rolę, uspokajając nastroje

${ }^{32}$ Turysta $w$ Czarnobylu, http://podroze.onet.pl/turysta-w-czarnobylu/ty439 [2011 r.]; Czarnobyl jako atrakcja turystyczna, http://tropster.pl/czarnobyl-jako-atrakcja-turystyczna/ [2016 r.]; Czarnobyl tour, http://www.bispol.com/czarnobyl-wycieczki/czarnobyl-tour [wycieczka $870 \mathrm{zł}$ ]; Czarnobyl Tour, http://www.quand.com.pl/wycieczka_czarnobyl.phtml [wycieczka od $275 \mathrm{zt}$ ]; Reise nach Tschernobyl, https:/www.chernobylwel.com/DE/781/ausflug-nach-tschernobyl-2-tage/ [279 euro]; Voyage à Tchernobyl, https://www.chernobylwel.com/FR/ (169-279 euro); Trip to Chernobyl, https://www.tourkiev.com/ [od 79 euro].

${ }^{33}$ E. Rosell, 30 år sen Tjernobyl...

${ }^{34}$ Wielki pożar w Czarnobylu! Istnieje zagrożenie dla Polski?, http://www.se.pl/wiadomosci/ swiat/wielki-pozar-w-czarnobylu-istnieje-zagrozenie-dla-polski_1006639.html.

${ }^{35}$ L. Feuerbach, Jodtabletten-Ausgabe in Aachen ,, Wir bereiten uns auf den atomaren Ernstfall vor", http://www.faz.net/aktuell/gesellschaft/gesundheit/kernkraftwerk-tihange-jodtabletten-fuer-alle-aachener-15178624.html; tejże, Angst vor Atomunfall. Nordrhein-Westfalen stockt Vorrat an Jodtabletten weiter auf, http://www.faz.net/aktuell/gesellschaft/ungluecke/nrw-stockt-vorrat-an-jodtabletten-auf-14376127.html.

${ }^{36}$ Gesprek met directie Tihange levertnietsop, https://www.laka.org/categorie/landen/belgie/ kerncentrale-tihange/page/2; Protest bij informatie bij eenkomstover Tihange, https://www.laka. org/categorie/landen/belgie/kerncentrale-tihange/page/2. 
lub podgrzewając je do granic, nad którymi nikt nie będzie w stanie zapanować ${ }^{37}$. Dziennik Polski24, powołując się na Se.p ${ }^{38}$, donosił, że Polacy wpadli w panikę, zaczęli masowo kupować tabletki ze stężonym jodem i płyn Lugola, zaś w sieci pojawiły się komentarze, sugerujące, że czeka nas „drugi Czarnobyl”. W mediach społecznościowych rozsyłano fałszywe wiadomości o treści: „Uwaga: Nad Polską znajduje się radioaktywna chmura (awaria reaktora jądrowego w Belgii). Lepiej żeby dziś i jutro przede wszystkim dzieci w ogóle nie wychodziły na dwór. Tej informacji niestety nie ma w serwisach, a jeśli są, to lakoniczne. Info jest od znajomego pracującego w Narodowym Centrum Badań Jądrowych. Weźcie kilka kropli płynu Lugola na pół szklanki wody. Prześlij dalej tę wiadomość”39. Tego typu działania, prowadzone nawet $\mathrm{w}$ dobrej wierze, w razie rzeczywistego zagrożenia znacznie utrudniłyby pracę służbom odpowiedzialnym za ewakuację i zabezpieczenie zaplecza socjalnego ewakuowanym. Wypływa z tego wniosek, że szykując się do działań kryzysowych, należy brać pod uwagę konsekwencje informatyzacji społeczeństwa. Przeciwko belgijskiej elektrowni 25 czerwca 2017 roku zaprotestowali mieszkańcy Belgii, Niemiec i Holandii, po raz kolejny żądając jej zamknięcia ${ }^{40}$.

${ }^{37}$ P. Stanisławski, Rzekoma awaria elektrowni atomowej w Belgii - nic złego się nie stało!, https://www.crazynauka.pl/rzekoma-awaria-elektrowni-atomowej-w-belgii-nic-zlego-sie-nie-stalo/; J. Kefir, Czy w Belgii doszło do potężnej awarii elektrowni atomowej?! Skażenie radioaktywne jest ukrywane?!, https://jarek-kefir.org/2017/09/05/czy-w-belgii-doszlo-do-poteznej-awarii-elektrowni-atomowej-skazenie-radioaktywne-jest-ukrywane/; Niemcy - Władze Akwizgranu rozdaja tabletki z jodem, boją się belgijskiej elektrowni atomowej w Tihange, która znajduje się $70 \mathrm{~km}$ od granicy, http://losyziemi.pl/niemcy-wladze-akwizgranu-rozdaja-tabletki-z-jodem-boja-sie-belgijskiej-elektrowni-atomowej-w-tihange-ktora-znajduje-sie-70-km-od-granicy.

${ }^{38}$ Awaria elektrowni atomowej w Belgii? Rząd uspokaja, Polacy kupuja jod, http:// www.se.pl/wiadomosci/swiat/awaria-elektrowni-atomowej-w-belgii-rzad-uspokaja-polacy-kupuja-jod_1016268.html.

${ }^{39}$ Awaria elektrowni atomowej w Belgii? Polacy kupuja jod i plyn Lugola, http://www.dziennikpolski24.pl/aktualnosci/a/awaria-elektrowni-atomowej-w-belgii-polacy-kupuja-jod-i-plyn-lugola,12444156/.

${ }^{40}$ Menselijke ketting tegen kerncentrale worstelt met geldproblemen, https://www.nu.nl/opmerkelijk/4743042/menselijke-ketting-kerncentrale-worstelt-met-geldproblemen.html?redirect=1; Waarom willen zoveel mensende Belgische kerncentrales dicht?, https://www.nu.nl/binnenland/4956047/waarom-willen-zoveel-mensen-belgische-kerncentrales-dicht.html; Actiegroepen 'teleurgesteld' na gesprek kerncentrales België over risico's, https://www.nu.nl/algemeen/4955084/ actiegroepen-teleurgesteld-gesprek-kerncentrales-belgie-risicos.html; 'Haarscheurtjes kerncentrales België al bij bouw ontdekt', https://nos.nl/artikel/2194360-haarscheurtjes-kerncentrales-belgie-al-bij-bouw-ontdekt.html;Groot protest tegen Belgische kerncentrale: 50.000 mensen vormen ketting in drie landen, https://www.volkskrant.nl/buitenland/groot-protest-tegen-belgische-kerncentrale-50-000-mensen-vormen-ketting-in-drie-landen a4502630. 
Powołując się na Państwową Agencję Atomistyki (PAA), niektóre media uspokajały Polaków, że rozdawanie tabletek było działaniem prewencyjnym, gdyż według niemieckich lokalnych władz istniało zagrożenie spowodowane prawdopodobnym pęknięciem obudowy zbiornika ciśnieniowego ${ }^{41}$. Co ciekawe, jedni pisali o awarii, inni tylko o pęknięciach i możliwej awarii w bliżej nieokreślonej przyszłości - kolejny przykład dezinformacji. Powołując się na PAA, pisano: „Dystrybucja tabletek ze stabilnym jodem na terenie okolic elektrowni jest działaniem wynikającym z polityki bezpieczeństwa i nie wynika $\mathrm{z}$ jakiejkolwiek sytuacji awaryjnej”’2. W mediach już w okresie awarii elektrowni w Fukushimie pojawiło się wiele artykułów odradzających picie płynu Lugola czy przyjmowania preparatów z jodem jako niebezpiecznych i nieskutecznych w pewnych warunkach. Nie chciano wywoływać reakcji, jaka miała miejsce po awarii elektrowni w Czarnobylu i Fukushimie - wykupywania preparatów i spekulowania nimi. Panika w tej materii może stanowić zagrożenie dla zdrowia społeczeństw ${ }^{43}$. We wrześniu tego roku pojawiła się także informacja o radioaktywnym obłoku nieznanego pochodzenia nad Europą, co po raz kolejny wywołało niepokój. Państwowa Agencja Atomistyki ustosunkowała się do tych obaw, informując o istniejącym stanie rzeczy w kontekście braku realnego zagrożenia ${ }^{44}$. Nie wszyscy jednak szukają informacji na stronach właściwych instytucji, zadowalając się wiadomością medialną. Jej nierzetelność może stanowić realny problem w sytuacji ewentualnego zagrożenia.

${ }^{41}$ Nie ma zagrożenia skażeniem. W elektrowni atomowej Tihange w Belgii nie doszło do awarii-uspokaja Państwowa Agencja Atomistyki, http://www.polsatnews.pl/wiadomosc/2017-09-02/ nie-ma-zagrozenia-skazeniem-w-elektrowni-atomowej-tihange-w-belgii-nie-doszlo-do-awarii-uspokaja-panstwowa-agencja-atomistyki/; Awaria elektrowni atomowej w Belgii? Ekspert mówi o,,bolesnej prawdzie”, http://superbiz.se.pl/opinie-biz/awaria-elektrowni-atomowej-w-belgii-ekspert-mowi-o-bolesnej-prawdzie_1016489.html.

${ }^{42}$ Awaria elektrowni atomowej w Belgii? Ekspert mówi o ,,bolesnej prawdzie”...

43 „Władze Belgii pierwszego września rozpoczęły akcję rozdawania obywatelom swojego kraju tabletek z jodem. Gdy ta informacja dotarła do Polski, mieszkańcy naszego kraju zaczęli bać się radioaktywnej chmury" - Awaria elektrowni atomowej w Belgii? Polacy kupuja jod...

${ }^{44}, \mathrm{~W}$ związku z pojawiającymi się informacjami medialnymi o potwierdzeniu pochodzenia izotopu rutenu-106, informujemy, że nad Polską na przełomie września i października wykryto krótkookresowo bardzo niewielkie stężenie tego izotopu. Ruten-106 był wykrywalny na precyzyjnych urządzeniach pomiarowych przez ok. 2 tygodnie na przełomie września i października. Po tym okresie jego stężenie spadło i obecnie izotop ten nie jest wykrywany. Wykryte stężenie rutenu-106 nie ma i nie miało żadnego wpływu na zdrowie mieszkańców Polski" - Brak obecności rutenu-106 w Polsce - aktualizacja, PAA, http://www.paa.gov.pl/aktualnosc-333-brak_obecnosci_rutenu_106_w_polsce.html. 
Holandia zasadniczo nie ucierpiała po katastrofie w Czarnobylu, ale rząd został zmobilizowany do podjęcia działań prewencyjnych. Holendrzy, jak wspomniano, doprowadzili do stworzenia NPK. Narodowy Instytut Zdrowia Publicznego i Środowiska (RIVM) otrzymał w NPK zadanie zbudowania sieci ostrzegawczej oraz, w razie incydentu, do odwzorowania sytuacji radiacyjnej na podstawie pomiarów i obliczeń modelu. W tym czasie utworzono także centrum informacji i dokumentacji w zakresie zapobiegania wypadkom jądrowym (IDC). Modele i systemy informacyjne IDC mogą zobrazować konsekwencje możliwego zagrożenia. W marcu 2011 roku Holandia mogła ocenić dokonane zmiany, jednak awaria w elektrowni jądrowej w Fukushimie była zupełnie innym rodzajem wypadku niż ta w Czarnobylu. Z perspektywy czasu wiemy, że Fukushima wypuściła o dziesięć razy mniej cząstek radioaktywnych niż elektrownia w Czarnobylu, poza tym leży z dala od Europy. Oceniając awarię w Czarnobylu z perspektywy lat, można stwierdzić, że znacznie wpłynęła ona na poprawę przygotowania i podejście do incydentów jądrowych. Holendrzy są przekonani, że w ciągu ostatnich dwudziestu lat wpływ promieniowania po awarii w Czarnobylu na mieszkańców w Holandii był znikomy. RIVM stale pracuje nad zapewnieniem holenderskiemu rządowi optymalnego wsparcia podczas ewentualnej katastrofy jądrowej i skażenia radioaktywnego. Urządzenia do monitorowania są stale ulepszane. Krajowa Sieć Monitorowania Promieniowania została rozszerzona o mobilne stanowiska pomiarowe. Nowa generacja pojazdów do pomiaru promieniowania, którymi dysponuje, została przystosowana także do użycia po ewentualnym ataku terrorystycznym z wykorzystaniem brudnej bomby.

Elektrownia we Flamanville we Francji z powodu wyeksploatowanych reaktorów może stać się „drugą Fukushimą”, jak wynika z wiadomości wyłuskiwanych z Internetu. W 2017 roku Francja dostarczyła Europie powodu do obaw - w lutym 2017 roku w elektrowni we Flamanville doszło do wybuchu, spowodowanego ,incydentem technicznym”. Francuzi od dłuższego czasu są świadomi zagrożenia, dlatego w październiku 2017 roku rozpoczęły się w tej elektrowni testy reaktora nowej generacji, który w 2018 roku ma zastąpić ten zużyty ${ }^{45}$. Ponownie francuskie elektrownie przypomniały się w czerwcu 2017 roku pożarem w Bugey w południowo-wschodniej Francji ${ }^{46}$. W lutym 2017 roku, z braku

45 J.D. Renard, Flamanville: EDF confirme le démarrage de son EPR à la fin 2018, http:// www.sudouest.fr/2017/10/09/flamanville-edf-confirme-le-demarrage-de-son-epr-a-lafin-2018-3846515-706.php.

${ }^{46}$ Francja: pożar $w$ elektrowni atomowej ugaszony, skażeń nie byto, http://www.wnp.pl/ wiadomosci/pozar-w-elektrowni-atomowej-we-francji,300511_1_0_0.html. 
pewnych informacji, spekulowano o wybuchu w reaktorze we Flamanville, do czasu podania oficjalnego komunikatu o przyczynie i przebiegu wypadku. Elektrownia ta znajduje się nad morzem, co budziło określone skojarzenia i kierowało wyobraźnię w kierunku możliwości rozniesienia skażenia na duże obszary za pośrednictwem wody ${ }^{47}$. Towarzyszyły temu relacje na żywo spod elektrowni, doniesienia prasowe, które podgrzewały atmosferę. W czerwcu Francuski Państwowy Instytut Ochrony Radiologicznej i Bezpieczeństwa Nuklearnego (IRSN) poinformował na Twitterze, że czujniki nie wykryły wzrostu poziomu promieniowania. Francuzi pamiętają wydarzenia w Fukushimie, ich media i francuska komórka Greenpeace oraz współpracujący z nimi przedstawiciele „Czarnobyla” nawołują od dłuższego czasu do refleksji ${ }^{48}$. Działacze i zwykli ludzie pod wpływem informacji zdobywanych w mediach domagają się zmian. Powołują się na wyniki publikowanych badań, wskazując na konsekwencje awarii tego typu elektrowni trwające latami, niemożliwe do usunięcia w krótkim czasie, generujące ogromne koszty przywrócenia środowiska naturalnego do stanu sprzed awarii i koszty społeczne.

Z mediów (np. belgijskich) można się dowiedzieć, że „Niemieckie badanie z 2013 roku pokazuje, że po katastrofie w Czarnobylu urodziło się w Rosji więcej chłopców niż dziewcząt. Dzieje się tak również na Kubie, ponieważ w latach 80. ubiegłego wieku Kuba była zależna w $60 \%$ od żywności (zanieczyszczonej radioaktywnie) z Rosji. Eksperymenty z promieniowaniem u zwierząt dają możliwe wyjaśnienie wzrostu liczby urodzeń chłopców. Testy te pokazują, że promieniowanie radioaktywne powoduje uszkodzenie chromosomu X w plemniku"49. Katastrofa nuklearna w Czarnobylu również miała przełożenie na zdrowie belgijskiej młodzieży. Badanie przeprowadzone przez szpital uniwersytecki Mont-Godinne (UCL) pokazuje, że młodzi ludzie, którzy mieli w dniu katastrofy

\footnotetext{
${ }^{47}$ Wybuch we francuskiej elektrowni jadrowej. Pożar opanowany, https://www.tvn24.pl/wiadomosci-ze-swiata,2/francja-wybuch-w-elektrowni-jadrowej,714147.html; Media: nawet 100 powaznych anomalii we francuskich elektrowniach atomowych, https://www.tvn24.pl/wiadomosci-ze-swiata,2/niepokoj-po-wybuchu-w-elektrowni-atomowej-we-flamanville,714479.html; Pożar w elektrowni atomowej we Francji ugaszony, http://www.polsatnews.pl/wiadomosc/2017-06-19/ pozar-w-elektrowni-atomowej-we-francji-ugaszony/.
}

${ }^{48}$ Bordeaux: l'entrée de l'Autorité de sûreté nucléaire murée par les écologistes, http:// www.sudouest.fr/2017/09/28/bordeaux-1-entree-de-1-autorite-de-surete-nucleaire-muree-par-lesecologistes-3815142-2780.php; Un tiers du parc nucléaire d'EDF est à l'arrêt, http://www.lemonde.fr/economie/article/2016/10/18/edf-va-mettre-a-l-arret-cinq-reacteurs-nucleaires-pour-reviser-leurs-cuves_5015903_3234.html\#9bQWEIKiYYFkfqTt.99.

${ }^{49}$ Tsjernobyl: 7 gevolgen... 
15 lat (1986 r.), znacznie częściej od innych roczników zapadają na raka tarczy$\mathrm{cy}^{50}$. Informacje, nawet jeżeli podawane są w formie uspokajającej, i tak budzą przerażenie. „Wedle dostępnych danych UNSCEAR, czyli Komitetu Naukowego ONZ ds. Skutków Promieniowania Atomowego, na dotkniętych katastrofą obszarach Rosji, Białorusi i Ukrainy odnotowano po katastrofie przeszło 6 tysięcy przypadków raka tarczycy, jednak tylko 15 z nich zakończyło się zgonem pacjenta. Przy tym oczywiście nie wszystkie te przypadki są wywołane katastrofą czarnobylską, niemniej przyjmuje się, że większość jest" ${ }^{\text {"51 }}$. Kładzie się nacisk na fakt, że do takiej liczby zachorowań doprowadziło przyzwolenie na spożywanie żywności, która była wytwarzana z produktów pochodzących ze skażonej strefy. Wiele kobiet przerażonych doniesieniami mediów o mutacjach popromiennych przerywało ciążę, by nie urodzić „mutanta”. Perypetie przeżywały instytucje, które, aby złagodzić strach, unikały określenia ,jądrowy”: „Niemiecki Ośrodek Badań Jądrowych w Karlsruhe z obawy przed cofnięciem finansowania przez rząd (notabene »zielonych«) zmienił swoją nazwę na »Ośrodek Badawczy«, a ceniona metoda obrazowania ludzkiego ciała, bazująca na »magnetycznym rezonansie jądrowym《 przyjęła nazwę »obrazowania magnetycznym rezonansem«, czyli MRI"52. Są to tylko nieliczne przykłady wywołanej przez media paniki, która powraca w słabszej formie, karmiona przez sensacyjne doniesienia ${ }^{53}$. Wydarzenia w Fukushimie także zaczynają obrastać własną „czarną legendą”, wpływającą na postrzeganie świata i zagrożeń przez ludzi ${ }^{54}$. Większość osób nie

\footnotetext{
${ }^{50}$ Tamże.

${ }^{51}$ Czarnobyl 27 lat później, http://adamrajewski.natemat.pl/59257,czarnobyl; A. Strupczewski,
} Skutki zdrowotne awarii w Czarnobylu...; W 20-ta rocznicę awarii czarnobylskiej elektrowni jadrowej, oprac. W. Trojanowski, L. Dobrzyński, E. Droste, Dział Szkolenia i Doradztwa Instytutu Problemów Jądrowych, marzec 2006, http://www.paa.gov.pl/uploads/pub/pages/page_163/ text_images/czarnobyl.pdf.

${ }^{52}$ W 20-ta rocznice awarii czarnobylskiej elektrowni jądrowej...

${ }^{53}$ Dzieci Czarnobyla - wstrzasające zdjęcia ofiar katastrofy, https://www.papilot.pl/zycie/ dzieci-czarnobyla-wstrzasajace-zdjecia-ofiar-katastrofy,10290,1; Przestali być ludźmi, stali sie obiektami radioaktywnymi. 27 lat temu wybucht reaktor $w$ Czarnobylu [FRAGMENTY KSIĄŻKI], http://wiadomosci.gazeta.pl/wiadomosci/1,114871,13810331,Przestali_byc_ludzmi_stali_ sie_obiektami_radioaktywnymi_html.

${ }^{54}$ Nowe zdjęcia mutantów z Fukushimy porazily świat, http://zmianynaziemi.pl/wideo/nowe-zdjecia-mutantow-fukushimy-porazily-swiat; Wykryto poważne zmiany genetyczne u motyli z Fukushimy, http://naukawpolsce.pap.pl/aktualnosci/news\%2C391301\%2Cpowazne-zmiany-genetyczne-u-motyli-z-fukushimy.html; Plaga zmutowanych motyli w Japonii, http://www.nationalgeographic.pl/przyroda/plaga-zmutowanych-motyli-w-japonii. 
zastanawia się nad obiektywizmem przekazywanych zdjęć czy informacji i źródłem ich pochodzenia.

Awaria Fukushimy nie wywołała tak dramatycznych skutków, jak skażenie po katastrofie w Czarnobylu, gdyż praktycznie natychmiast zabroniono spożywania wszystkiego, co pochodziło z potencjalnie skażonych obszarów. Upowszechniona wiedza zapobiegła niewątpliwie wielu tragediom. Media przestrzegają, że sześć lat po katastrofie Japończycy nadal borykają się ze skażeniem i jego dalekosiężnymi konsekwencjami społecznymi, gospodarczymi i etycznymi (np. gdy trzeba wybijać skażone zwierzęta, zwłaszcza zagrażające ludziom dziki) ${ }^{55}$. „The New York Times” donosił, że ulice japońskich miast i wsi dotkniętych katastrofą przypominają Czarnobyl, gdzie dzika przyroda rozwija się pomimo wysokiego poziomu promieniowania ${ }^{56}$. Według doniesień japońskiej gazety „Yomiuri” dziki wyrządziły szkody w rolnictwie w prefekturze Fukushima na kwotę około 854000 dolarów ${ }^{57}$. W opuszczonych sklepach i supermarketach mnożą się stada szczurów, co może nieść duże zagrożenie epidemiologiczne. Ludzie obawiają się powrotu na swoje ziemie z powodu dzikich zwierząt, które opanowały teren. W 2014 roku, według doniesień medialnych, liczba zabitych w Japonii dzików wzrosła na zamkniętym obszarze z 3000 do 13000 sztuk. Potencjalni mieszkańcy obawiają się także skutków rozkładu radioaktywnych organizmów zwierząt. Padają także pytania, czy gdyby utylizację ciał zwierząt prowadzić poprzez kremację, radioaktywne cząstki nie przedostaną się do atmosfery i nie skażą jej. Mieszkańcy skarżą się, że rząd Japonii działa opieszale, a walka ze zwierzętami ma jedynie uspokoić Japończyków przed zbliżającymi się w 2020 roku igrzyskami w Tokyo ${ }^{58}$.

\footnotetext{
${ }^{55}$ Six ans après Fukushima, des sangliers radioactifs viennent troubler le retour des habitants, Franceinfo, http://www.francetvinfo.fr/monde/japon/fukushima/des-sangliers-radioactifsviennent-troubler-le-retour-des-habitants-de-fukushima-six-ans-apres-la-catastrophe_2090291. html; Six ans après la catastrophe de Fukushima: „La situation japonaise doit servir à alerter la France", Franceinfo, http://www.francetvinfo.fr/monde/japon/fukushima/six-ans-apres-la-catastrophe-de-fukushima-la-situation-japonaise-doit-servir-a-alerter-la-france_2091999.html.

${ }^{56}$ K. de Frejtas-Tamura, Radioactive Boars in Fukushima Thwart Residents' Plans to Return Home, „The New York Times”, 9.03.2017, https://www.nytimes.com/2017/03/09/world/asia/radioactive-boars-in-fukushima-thwart-residents-plans-to-return-home.html?smid=tw-nytimesworld\& smtyp=cur\&_r=1.

57 Tamże.

${ }^{58}$ M. Thomas, Fukushima: six ans après la catastrophe nucléaire, des milliers de sangliers radioactifs ralentissent le retour de la population, „L'Independent”, 11.03.2017, http://www.lindependant.fr/2017/03/11/fukushima-six-ans-apres-la-catastrophe-nucleaire-des-milliers-sangliersradioactifs-ralentissent-le-retour-de-la-population,2295977.php.
} 
Charakterystyczny po awarii w Fukushimie jest brak zaufania społeczeństw do własnych rządów, niedowierzanie, że jest bezpiecznie, że żywność jest bezpieczna. Nakłada się to na doświadczenia wcześniejsze: „(...) nie wolno także zapomnieć o poważnych skutkach psychologicznych katastrofy czarnobylskiej, pogłębionych dodatkowo polityką informacyjną władz radzieckich w okresie bezpośrednio po katastrofie" 59 . Nawet mało aktywne przed 2011 roku społeczeństwo Japonii „obudziło się”, ludzie organizują się, aby walczyć o obowiązkowe badania profilaktyczne w kierunku nowotworów, oddają do ekspertyz niezależnych laboratoriów próbki żywności. Aktywiści organizacji ekologicznych i konsumenckich za pomocą liczników Geigera kontrolują żywność w sklepach. Nawet zapewnienie cesarza, że rodzina cesarska je ryż z terenów objętych kataklizmem, nie zatrzymało fali nieufności. Część obywateli kupuje żywność ze sprawdzonych źródeł przez Internet. Rząd Japonii wydaje mnóstwo pieniędzy na badanie produktów rolnych i certyfikaty bezpieczeństwa japońskiej żywności. Uzyskał nawet pozytywne opinie FAO i WHO w tej materii. Pomimo to Japończykom trudno jest wejść ponownie na rynki żywności. Ludzie pamiętają strach przed śmiercią w wyniku napromieniowania. Po lekturze internetowych stron europejskich organizacji zajmujących się bezpieczeństwem radiologicznym i żywności można wysnuć wniosek, że także Europejczycy drążą temat skażeń, nie zawsze wierząc w uspokajające zapewnienia instytucji państwowych.

Prasa zaczęła rozpisywać się o szkodliwości płynu Lugola, starając się odwieść ludzi od jego nieuzasadnionego spożywania. Nie zawsze daje to jednak rezultaty. Rząd Belgi, jak wspomniano, w obliczu wielokrotnych awarii elektrowni jądrowej Tihange postanowił „na wszelki wypadek” zabezpieczyć obywateli $\mathrm{w}$ ten specyfik ${ }^{60}$. Ma być on zażyty wówczas, kiedy dojdzie do incydentu zagrażającego zdrowiu ludzi. Rodzi się pytanie, dlaczego zamiast wyłączyć elektrownię naraża się własny naród, a być może i sąsiednie kraje. Płyn Lugola czy tabletki jodu pojawiły się jako antidotum na promieniowanie po awarii w Czarnobylu. Rząd polski zdecydował wówczas o zastosowaniu płynu i, jak donosi PAA, 75\%

${ }^{59}$ Czarnobyl 27 lat później...

${ }^{60}$ „Elektrownia jądrowa Tihange na terenie Belgii spędza sen z powiek mieszkańcom pobliskich terenów. W każdej chwili może tam dojść do awarii, dlatego władze miasta postanowiły wydawać tabletki jodu. Istnieje prawdopodobieństwo, że w przypadku zagrożenia nie udałoby się tego zrobić na czas. Belgijska elektrownia od lat uważana jest za niebezpieczną i co jakiś czas dochodzi w niej do awarii” - K. Stabach, Elektrownia jądrowa zagrożona. Władze miasta rozdaja tabletki jodu, https://wiadomosci.wp.pl/elektrownia-jadrowa-zagrozona-wladze-miasta-rozdajatabletki-jodu-6161402180618369a. 
ówczesnej populacji, która powinna go otrzymać, dostała go prawie natychmiast po otrzymaniu wiadomości o zdarzeniu. Rząd USA zaczął zabezpieczać swoich obywateli dopiero po ośmiu dniach, a Rosja po miesiącu od katastrofy. Same preparaty i sposób ich zastosowania obrosły już własną legendą. Niektóre jej aspekty starają się prostować naukowcy. Belgowie w tabletki postanowili zaopatrzyć bezpłatnie osoby do 45. roku życia, kobiety w ciąży i karmiące matki. Belgijska Komisja Ochrony Radiologicznej odradza ich przyjmowanie osobom starszym, bowiem ryzyko wystąpienia u seniorów powikłań jest większe niż ryzyko zachorowania przez nich na raka tarczycy. Po wydarzeniach w Fukushimie wiele stron internetowych przedstawiło plusy, minusy i zasady zażywania tego typu preparatów. Ten kto szuka, znajdzie na stronach instytucji naprawdę rzetelny opis preparatów i wiążących się z ich zażyciem konsekwencji. Niestety szukanie informacji u źródła nie jest jak dotąd powszechne u użytkowników mass mediów.

Wiele elektrowni atomowych leży w pobliżu granic innych państw. Belgijska Tihange znajduje się około $70 \mathrm{~km}$ od granicy z Niemcami (Akwizgran). Nie tylko ich wiek, ale i całkiem realne zagrożenie atakiem terrorystycznym musi być obecnie brane pod uwagę przez służby odpowiedzialne za bezpieczeństwo infrastruktury krytycznej. Za przykład może posłużyć ponownie Belgia. W marcu 2016 roku, dwa dni po zamachach terrorystycznych w Brukseli, został zamordowany ochroniarz z elektrowni w Tihange. Jego przepustka służbowa zaginęła ${ }^{61}$. Belgijski dziennik „La Derniere Heure” poinformował wtedy, że przepustka została zablokowana natychmiast po wykryciu zabójstwa. Strażnik został zastrzelony niedaleko Charleroi w zachodniej Belgii. W tym kontekście Agencja Reutera przypomniała, że pod koniec 2015 roku służby prowadzące dochodzenie w sprawie listopadowych zamachów terrorystycznych w Paryżu natrafiły na ślady mogące świadczyć o tym, że islamiści mogli śledzić dyrektora belgijskiego programu badań jądrowych. Dziennik „La Derniere Heure" poinformował wręcz, że islamiści planowali atak terrorystyczny na elektrownię atomową w Belgii, a szefa programu atomowego śledzili przez co najmniej rok. Podobne zagrożenie stwarzają hakerzy ${ }^{62}$. Wraz ze wzrastającą liczbą groźnych zjawisk atmosferycznych typu huragan wymienione powyżej niebezpieczeństwa stanowią podstawę do poważnego zastanowienia się, na ile w istniejącej rzeczywistości jesteśmy przygotowani na przypadek wystąpienia kryzysu nuklearnego.

${ }^{61}$ Nie ma zagrożenia skażeniem...

${ }^{62}$ USA - hakerzy włamali się do sieci elektrowni atomowych, wykradli dane biznesowej części infrastruktury, http://losyziemi.pl/usa-hakerzy-wlamali-sie-do-sieci-elektrowni-atomowych-wykradli-dane-biznesowej-czesci-infrastruktury. 
Żyjemy w cieniu elektrowni jądrowych, oswajamy się ze skutkami awarii dzięki mediom i turystyce. Przedstawione powyżej fakty skłaniają do stawiania pytań. Jak przełożą się te doświadczenia na zachowania ludzi, gdy rzeczywiście dojdzie do zagrożenia? Czy zebrane „doświadczenia”, sposób mówienia o niebezpieczeństwie, podobnie jak w Japonii, nie skłonią jedynie części obywateli do ucieczki i wykonania poleceń dotyczących ewakuacji? Jak można wykorzystać media, aby w razie kryzysu były sprzymierzeńcem, a nie wrogiem ekip ratowniczych? Jak edukować ludzi, by rozsądnie korzystali z wiadomości niesionych przez media? Po wskazanych katastrofach, zwłaszcza awarii ostatniej w Tihange, rządy państw europejskich były zasypywane pytaniami od wystraszonych obywateli w kraju oraz tych, którzy pracowali w Japonii lub Azji, od firm, które zajmowały się transportem (zanieczyszczenie samolotów, kontenerów, statków, wszelkiego rodzaju pojazdów), eksporterów produktów rolnych i innych towarów z Japonii. Oznacza to, że będzie się oczekiwało od rządów skutecznej ochrony nie tylko życia, ale i mienia obywateli. Skala tego zjawiska będzie zależała od wyedukowania społeczeństwa i jego przygotowania do uczestniczenia w życiu państwa. Warto się nad tym zastanowić, budując scenariusze postępowania w sytuacji zagrożenia infrastruktury krytycznej.

\section{Bibliografia}

28 Jahre nach Tschernobyl, Wildschweine und Pilze strahlen weiter, http://www.n-tv. de/wissen/Wildschweine-und-Pilze-strahlen-weiter-article12721231.html (dostęp: 15.03.2013).

30 jaar Tsjernobyl, http://www.rivm.nl/Onderwerpen/O/Ongevallen_en_rampen/Kernongevallen/30_jaar_Tsjernobyl (dostęp: 15.03.2019).

Actiegroepen 'teleurgesteld' na gesprek kerncentrales België over risico's, https:// www.nu.nl/algemeen/4955084/actiegroepen-teleurgesteld-gesprek-kerncentrales-belgie-risicos.html (dostęp: 14.02.2019).

Awaria elektrowni atomowej w Belgii? Ekspert mówi o „bolesnej prawdzie”, http://superbiz.se.pl/opinie-biz/awaria-elektrowni-atomowej-w-belgii-ekspert-mowi-o-bolesnej-prawdzie_1016489.html (dostęp: 1.03.2019).

Awaria elektrowni atomowej w Belgii? Polacy kupuja jod i plyn Lugola, http:// www.dziennikpolski24.pl/aktualnosci/a/awaria-elektrowni-atomowej-w-belgii-polacy-kupuja-jod-i-plyn-lugola,12444156/ (dostęp: 20.02.2019).

Awaria elektrowni atomowej w Belgii? Rzad uspokaja, Polacy kupuja jod, http:// www.se.pl/wiadomosci/swiat/awaria-elektrowni-atomowej-w-belgii-rzad-uspokaja-polacy-kupuja-jod_1016268.html (dostęp: 20.02.2019). 
Bacon P., Hobson Ch., Human Security and Japan's Triple Disaster. Responding to the 2011 Earthquake, Tsunami and Fukushima Nuclear Crisis, Abington-New York 2014.

Bestrålning av livsmedel, Livsmedelsverket, https://www.livsmedelsverket.se/livsmedel-och-innehall/oonskade-amnen/radioaktivitet-och-bestralning/bestralning-av-livsmedel (dostęp: 15.03.2019).

Boos S., Fukushima lässt grüßen, Zürich 2012.

Bordeaux: l'entrée de l'Autorité de sûreté nucléaire murée par les écologistes, http:// www.sudouest.fr/2017/09/28/bordeaux-l-entree-de-l-autorite-de-surete-nucleairemuree-par-les-ecologistes-3815142-2780.php (dostęp: 5.03.2019).

Brak obecności rutenu-106 w Polsce - aktualizacja, PAA, http://www.paa.gov.pl/aktualnosc-333-brak_obecnosci_rutenu_106_w_polsce.html (dostęp: 8.03.2019).

Caldicott H., Crisis Without End: The Medical and Ecological Consequences of the Fukushima Nuclear Catastrophe, New York 2014.

Coulmas F., Stalpers J., Fukushima. Vom Erdbeben zur atomaren Katastrophe, München 2011.

Czarnobyl jako atrakcja turystyczna, http://tropster.pl/czarnobyl-jako-atrakcja-turystyczna/ (dostęp: 5.03.2019).

Czarnobyl 27 lat później, http://adamrajewski.natemat.pl/59257,czarnobyl (dostęp: 5.03.2019).

Dzieci Czarnobyla - wstrzasajace zdjęcia ofiar katastrofy, https://www.papilot.pl/zycie/dzieci-czarnobyla-wstrzasajace-zdjecia-ofiar-katastrofy,10290,1 (dostęp: 15.03.2019).

Ebermann L., Junkert A., Tschernobyl - 20 Jahre Danach, BundesamtfürStrahlenschutz, www.lehrer.uni-karlsruhe.de/ za976/strlschtz/../Tscherno20.pdf (dostęp: 5.03.2019).

Elliott D., Fukushima: Impacts and Implications, London 2012.

Fakty przeciwko mitom, http://strefaczarnobyl.republika.pl/fakty_przeciwko_mitom. html (dostęp: 5.03.2019).

Feuerbach L., Angst vor Atomunfall. Nordrhein-Westfalen stockt Vorrat an Jodtabletten weiter auf, http://www.faz.net/aktuell/gesellschaft/ungluecke/nrw-stockt-vorratan-jodtabletten-auf-14376127.html (dostęp: 18.01.2019).

Feuerbach L., Jodtabletten-Ausgabe in Aachen „Wir bereiten uns auf den atomaren Ernstfall vor", http:/www.faz.net/aktuell/gesellschaft/gesundheit/kernkraftwerk-tihange-jodtabletten-fuer-alle-aachener-15178624.html (dostęp: 18.01.2019).

Francja: pożar $w$ elektrowni atomowej ugaszony, skażeń nie było, http://www.wnp.pl/ wiadomosci/pozar-w-elektrowni-atomowej-we-francji,300511_1_0_0.html (dostęp: 5.03.2019). 
Freytas-Tamura K. de, Radioactive Boars in Fukushima Thwart Residents' Plans to Return Home, „The New York Times”, https:/www.nytimes.com/2017/03/09/world/ asia/radioactive-boars-in-fukushima-thwart-residents-plans-to-return-home.htm1?smid=tw-nytimesworld\&smtyp=cur\&_r=1 (dostęp: 5.03.2019).

Fukushima Daiichi Status Updates, IAEA, https://www.iaea.org/newscenter/focus/ fukushima/status-update (dostęp: 1.03.2019).

Fukushima evacuee to tell UN that Japan violated human rights, https:/www.theguardian.com/environment/2017/oct/11/fukushima-evacuee-un-japan-human-rights (dostęp: 1.03.2019).

Fukushima nuclear disaster: former Tepco executives go on trial, https://www.theguardian.com/environment/2017/jun/30/fukushima-nuclear-crisis-tepco-criminal-trial-japan (dostęp: 1.03.2019).

Geheimsache radioaktiv verstrahlte Wildsäue, „Welt”, 20.04.2015, https://www.welt.de/ wissenschaft/umwelt/article139797061/Geheimsache-radioaktiv-verstrahlte-Wildsaeue.html (dostęp: 15.01.2019).

Gesprek met directive Tihangelevertniets op, https://www.laka.org/categorie/landen/belgie/kerncentrale-tihange/page/2 (dostęp: 20.02.2019).

Giles J., Marris E., Indonesian tsunami-monitoring system lacked basic equipment, http:// www.nature.com/news/2004/041229/full/news041229-4.html (dostęp: 1.03.2015).

Glogg A., Keine Angst vor Fukushima?, Bichwil 2012.

Groot protest tegen Belgische kerncentrale: 50.000 mensen vormen ketting in drie landen, https://www.volkskrant.nl/buitenland/groot-protest-tegen-belgische-kerncentrale-50-000-mensen-vormen-ketting-in-drie-landen a4502630 (18.01.2019).

'Haarscheurtjes kerncentrales België al bij bouw ontdekt', https://nos.nl/artikel/2194360haarscheurtjes-kerncentrales-belgie-al-bij-bouw-ontdekt.html (18.01.2019).

Hatamura Y., Abe S., Fuchigami M., Kasahara N., The 2011 Fukushima Nuclear Power Plant Accident, Elsevier 2014.

Hindmarsh R., Nuclear Disaster at Fukushima Daiichi, Social, Political and Environmental Iussues, New York 2013.

Hirose T., Fukushima Meltdown: The World's First Earthquake-Tsunami-Nuclear Disaster, North Charleston, SC 2012.

Hubbard Ch., Fukushima and Beyond: Nuclear Power in a Low-Carbon World, Farnham 2014.

Ivarsson M., 30 år efter olyckan tar djuren över Tjernobyl, Allt Om Resor, https:// www.expressen.se/allt-om-resor/30-ar-efter-olyckan-tar-djuren-over-tjernobyl/ (dostęp: 16.03.2019).

Japanese government held liable for first time for negligence in Fukushima, https:// www.theguardian.com/world/2017/mar/17/japanese-government-liable-negligence-fukushima-daiichi-nuclear-disaster (dostęp: 1.03.2019). 
Kefir J., Czy w Belgii doszło do potężnej awarii elektrowni atomowej?! Skażenie radioaktywne jest ukrywane?!, https://jarek-kefir.org/2017/09/05/czy-w-belgii-doszlo-do-poteznej-awarii-elektrowni-atomowej-skazenie-radioaktywne-jest-ukrywane/ (dostęp: 16.03.2019).

Ladkin P.B., Goeker Ch., Sieker B., The Fukushima Dai-Ichi Accident, LIT Verlag 2013.

Lasy pod Opolem to najbardziej napromieniowane miejsce $w$ Polsce, https://kontakt24. tvn24.pl/lasy-pod-opolem-to-najbardziej-napromieniowane-miejsce-w-polsce,81601,ugc (dostęp: 8.01.2019).

Lista ujawnionych awarii elektrowni jądrowych na świecie, https://sites.google.com/site/ awarielektrowni/ (dostęp: 5.03.2019).

Mackenthun G., Fukushima, Norderstedt 2014.

Menselijke ketting tegen kerncentrale worstelt met geldproblemen, https://www.nu.nl/ opmerkelijk/4743042/menselijke-ketting-kerncentrale-worstelt-met-geldproblemen.html?redirect=1 (dostęp: 19.02.2019).

Międzynarodowe implikacje awarii elektrowni atomowej w Fukushimie. Wybrane aspekty problemu, red. R. Gałaj-Dempniak, Szczecin 2015.

Moran P.M., The Sushi-Eating Basset Hound from Fukushima Japan, North Charleston, SC 2013.

Nadesan M.H., Fukushima and the Privatization of Risk, London 2013.

Nakanishi T.M., Tanoi K., Agricultural Implications of the Fukushima Nuclear Accident, Springer 2013.

Nawet 100 powaznych anomalii we francuskich elektrowniach atomowych, https:// www.tvn24.pl/wiadomosci-ze-swiata,2/niepokoj-po-wybuchu-w-elektrowni-atomowej-we-flamanville,714479.html (dostęp: 4.01.2019).

Nie ma zagrożenia skażeniem. W elektrowni atomowej Tihange w Belgii nie doszło do awarii - uspokaja Państwowa Agencja Atomistyki, http://www.polsatnews.pl/wiadomosc/2017-09-02/nie-ma-zagrozenia-skazeniem-w-elektrowni-atomowej-tihange-w-belgii-nie-doszlo-do-awarii-uspokaja-panstwowa-agencja-atomistyki//dostęp: 5.03.2019).

Niemcy - Władze Akwizgranu rozdaja tabletki z jodem, boja się belgijskiej elektrowni atomowej $w$ Tihange, która znajduje się $70 \mathrm{~km}$ od granicy, http://losyziemi.pl/niemcy-wladze-akwizgranu-rozdaja-tabletki-z-jodem-boja-sie-belgijskiej-elektrowni-atomowej-w-tihange-ktora-znajduje-sie-70-km-od-granicy (dostęp: 5.03.2019).

Nowe zdjęcia mutantów z Fukushimy poraziły świat, http://zmianynaziemi.pl/wideo/nowe-zdjecia-mutantow-fukushimy-porazily-swiat (dostęp: 17.03.2019).

Ochiai E., Hiroshima to Fukushima: Biohazards of Radiation, Springer 2014.

Pilze in bayerischen Wäldern nach wie vor radioaktiv verseucht, Proplanta, 27.09.2017, http://m.proplanta.de/Agrar-Nachrichten/Verbraucher/Pilze-in-bayerischen-Waeldern-nach-wie-vor-radioaktiv-verseucht_article1506470529.html (dostęp: 9.03.2019). 
Pożar w elektrowni atomowej we Francji ugaszony, http://www.polsatnews.pl/wiadomosc/2017-06-19/pozar-w-elektrowni-atomowej-we-francji-ugaszony/ (dostęp: 12.03.2019).

Protest bij informatiebijeenkomst over Tihange, https:/www.laka.org/categorie/landen/ belgie/kerncentrale-tihange/page/2 (dostęp: 20.02.2019).

Province P., Hirose K., Aoyama M., Fukushima Accident: Radioactivity Impact on the Environment, Elsevier 2013.

Radiation Monitoring and Dose Estimation of the Fukushima Nuclear Accident, red. S. Takahashi, Springer 2014.

Radioaktive Verseuchung tschechischer Wildschweine hält an, Proplanta, 19.01.2017, http://m.proplanta.de/Agrar-Nachrichten/Umwelt/Radioaktive-Verseuchung-tschechischer-Wildschweine-haelt-an_article1484837806.html (dostęp: 10.03.2019).

Radioaktivität in Baden-Württemberg, Landesanstalt für Umwelt, Messungen und Naturschutz Baden-Württemberg, Karlsruhe 2012, https://www4.lubw.baden-wuerttemberg.de/.../radioaktivitaet_200(dostęp: 20.01.2019).

Radioaktiva ämnen - cesium, Livsmedelsverket, https://www.livsmedelsverket.se/livsmedel-och-innehall/oonskade-amnen/radioaktivitet-och-bestralning/radioaktiva-amnen (dostęp: 15.03.2019).

Radioaktivt cesium $i$ vildsvin, Livsmedelsverket, https://www.livsmedelsverket.se/livsmedel-och-innehall/oonskade-amnen/radioaktivitet-och-bestralning/radioaktivt-cesium-i-vildsvin-fragor-och-svar (dostęp: 8.03.2019).

Reflections on the Fukushima Daiichi Nuclear Accident: Toward Social-Scientific Literacy and Engineering Resilience, red. J. Ahn, C. Carson, S. Nagasaki, M. Jensen, K. Juraku, S. Tanaka, Springer 2015.

Renard J.D., Flamanville: EDF confirme le démarrage de son EPR à la fin 2018, http:// www.sudouest.fr/2017/10/09/flamanville-edf-confirme-le-demarrage-de-son-epra-la-fin-2018-3846515-706.php (dostęp: 5.03.2019).

Roberson K., Silence Deafening, Fukushima Fallout... a Mother's Response, North Charleston 2013.

Rosell E., 30 år sen Tjernobyl - sammanfattning av konsekvenserna för människor och miljö, http://supermiljobloggen.se/nyheter/2016/04/30-ar-sen-tjernobyl-sammanfattning-av-konsekvenserna-for-manniskor-och-miljo (dostęp: 5.03.2019).

Six ans après Fukushima, des sangliers radioactifs viennent troubler le retour des habitants, Franceinfo, http://www.francetvinfo.fr/monde/japon/fukushima/dessangliers-radioactifs-viennent-troubler-le-retour-des-habitants-de-fukushima-sixans-apres-la-catastrophe_2090291.html (dostęp: 6.03.2019).

Six ans après la catastrophe de Fukushima: „La situation japonaise doit servir à alerter la France”, Franceinfo, http://www.francetvinfo.fr/monde/japon/fukushima/sixans-apres-la-catastrophe-de-fukushima-la-situation-japonaise-doit-servir-a-alerter-la-france_2091999.html (dostęp: 5.03.2019). 
Stabach K., Elektrownia jądrowa zagrożona. Władze miasta rozdaja tabletki jodu, https:// wiadomosci.wp.pl/elektrownia-jadrowa-zagrozona-wladze-miasta-rozdaja-tabletki-jodu-6161402180618369a (dostęp: 5.01.2019).

Stanisławski P., Rzekoma awaria elektrowni atomowej w Belgii - nic złego się nie stało!, https://www.crazynauka.pl/rzekoma-awaria-elektrowni-atomowej-w-belgii-nic-zlego-sie-nie-stalo/ (dostęp: 16.01.2019).

Strahlende Zukunft für Europas Osten, https://www.mdr.de/heute-im-osten/kernkraftosteuropa-100.html (dostęp: 25.01.2019).

Strupczewski A., Skutki zdrowotne awarii w Czarnobylu, http://atom.edu.pl/index.php/ bezpieczenstwo/prawda-o-czarnobylu/skutki-zdrowotne.html (dostęp: 15.03.2019).

Symonds P., The Asian Tsunami: Why There Were No Warnings, http://www.wsws.org/ en/articles/2005/01/warn-j03.html (dostęp: 5.03.2015).

The Fukushima Daiichi Nuclear Accident: Final Report of the AESJ Investigation Committee, Atomic Energy Society of Japan, Springer 2014.

The Fukushima Daiichi Nuclear Power Station Disaster: Investigating the Myth and Reality, red. M.K. Bricker, London 2014.

Thomas M., Fukushima: six ans après la catastrophe nucléaire, des milliers de sangliersradioactifsralentissent le retour de la population, „L'Independent”, 11.03.2017, http://www.lindependant.fr/2017/03/11/fukushima-six-ans-apres-la-catastrophenucleaire-des-milliers-sangliers-radioactifs-ralentissent-le-retour-de-la-population,2295977.php (dostęp: 8.02.2019).

Tjernobylolyckan - läget efter 25 år, https://www.livsmedelsverket.se/globalassets/ livsmedel-innehall/oonskade-amnen/radioaktivitet/tjernobylolyckan--laget-efter-25-ar.pdf (dostęp: 15.03.2019).

Tsjernobyl: 7 gevolgen van een 30-jarige kernramp, http://www.knack.be/nieuws/planetearth/tsjernobyl-7-gevolgen-van-een-30-jarige-kernramp/article-normal-692851. html (dostęp: 15.02.2019).

Turysta w Czarnobylu, http://podroze.onet.pl/turysta-w-czarnobylu/ty439 (dostęp: 15.02.2019).

Un tiers du parc nucléaire d'EDF est à l'arrêt, http://www.lemonde.fr/economie/article/2016/10/18/edf-va-mettre-a-1-arret-cinq-reacteurs-nucleaires-pour-reviserleurs-cuves_5015903_3234.html\#9bQWEIKiYYFkfqTt.99 (dostęp: 8.03.2019).

USA - Hakerzy włamali się do sieci elektrowni atomowych, wykradli dane biznesowej części infrastruktury, http://losyziemi.pl/usa-hakerzy-wlamali-sie-do-sieci-elektrowni-atomowych-wykradli-dane-biznesowej-czesci-infrastruktury (dostęp: 5.03.2019).

W 20-ta rocznice awarii czarnobylskiej elektrowni jadrowej, oprac. W. Trojanowski, L. Dobrzyński, E. Droste, Dział Szkolenia i Doradztwa Instytutu Problemów Jądrowych, marzec 2006, http://www.paa.gov.pl/uploads/pub/pages/page_163/text_images/czarnobyl.pdf (dostęp: 5.03.2019). 
Waarom willen zoveel mensen de Belgische kerncentrales dicht?, https://www.nu.nl/ binnenland/4956047/waarom-willen-zoveel-mensen-belgische-kerncentralesdicht.html (dostęp: 11.03.2019).

Wielki pożar w Czarnobylu! Istnieje zagrożenie dla Polski?, http://www.se.pl/wiadomosci/swiat/wielki-pozar-w-czarnobylu-istnieje-zagrozenie-dla-polski_1006639. html (dostęp: 9.02.2019).

Wildschweine auch 25 Jahre nach Tschernobyl verstrahlt, Proplanta, 17.03.2011, http:// m.proplanta.de/Agrar-Nachrichten/Umwelt/Wildschweine-auch-25-Jahre-nachTschernobyl-verstrahlt_article1300384973.html (dostęp: 17.03.2019).

DeWit A., Japan's „National Resilience” and the Legacy of 3-11, „The Asia-Pacific Journal" 2016, Vol. 14 (6), No. 1, https://apjjf.org/-Andrew-DeWit/4870/article.pdf (dostęp: 15.03.2019).

Wybuch we francuskiej elektrowni jadrowej. Pożar opanowany,https://www.tvn24.pl/ wiadomosci-ze-swiata,2/francja-wybuch-w-elektrowni-jadrowej,714147.html (dostęp: 17.01.2019).

Wykryto poważne zmiany genetyczne u motyli z Fukushimy, http://naukawpolsce.pap.pl/ aktualnosci/news\%2C391301\%2Cpowazne-zmiany-genetyczne-u-motyli-z-fukushimy.html; Plaga zmutowanych motyli w Japonii, http://www.national-geographic. pl/przyroda/plaga-zmutowanych-motyli-w-japonii (dostęp: 17.03.2019).

Zasuń R., Wieliński B., Niemcy do 2021 r. wyłacza elektrownie atomowe, http://wyborcza.pl/1,155287,9696034,Niemcy_do_2021_r__wylacza_elektrownie_atomowe. html?disableRedirects=true (dostęp: 5.03.2019).

$\mathrm{zdr} / \mathrm{ml} /$, Rekordowo napromieniowany dzik $w$ Szwecji. 31 lat po katastrofie $w$ Czarnobylu, Polsat News, http://www.polsatnews.pl/wiadomosc/2017-10-06/napromieniowane-dziki-w-szwecji-31-lat-po-katastrofie-elektrowni-jadrowej-w-czarnobylu/ (dostęp: 5.03.2019).

\begin{abstract}
Abstrakt
Są wydarzenia, które zmieniają spojrzenie naukowców, wojskowych, a także społeczeństw na stabilność i bezpieczeństwo świata, otoczenia i własnego życia. Do takich należy niewątpliwie awaria elektrowni atomowej w Fukushimie, spowodowana tsunami. Wydarzenie to porównywane jest przez media zarówno do Hiroszimy, jak i Czarnobyla. We współczesnej Europie podobne zagrożenie stwarzają wyeksploatowane elektrownie francuskie (np. Flamanville) i belgijskie (np. Tihange), zwłaszcza te położone w pobliżu mórz. Przy wyjątkowo niekorzystnych warunkach atmosferycznych mogą skazić nie tylko zasoby wodne, ale i żywność w Europie. Do dzisiaj opad promieniotwórczy po Czarnobylu zalega, przenikając do potencjalnych źródeł karmy dla zwierząt i pożywienia
\end{abstract}


ludzi. Nie bez kozery ekolodzy i zwykli ludzie, pomni na doświadczenia z przeszłości, domagają się zamknięcia niebezpiecznych elektrowni. Problem polega na tym, że trudno je zastąpić, wytwarzając odpowiednią ilość energii w alternatywny sposób. Podobne zagrożenie stwarzają hakerzy, dokonujący aktów terrorystycznych. Przejęcie przez nich kontroli nad systemami infrastruktury krytycznej zagraża całemu kontynentowi. Wraz ze wzrastającą liczbą agresywnych zjawisk typu huragan wymienione powyżej zagrożenia stanowią podstawę do poważnego zastanowienia się, na ile w istniejącej rzeczywistości jesteśmy przygotowani do ewakuacji i zabezpieczenia ludzi w razie wystąpienia kryzysu nuklearnego. Trzeba także pamiętać, że doświadczenia po przebytych awariach uczą, że zachowanie ludzi w chwilach kryzysu jest jednak nieprzewidywalne i może się okazać, iż nie wszystkim zdoła się pomóc.

\title{
Nuclear Power Plant Failures and their Impact on the Critical INFRASTRUCTURE AND THE LIFE OF THE EUROPEAN SOCIETIES EXEMPLIFIED with the Failures in Fukushima, Chernobyl and Tihange in the Context of Media Information
}

\begin{abstract}
There are events that change the approach of the scholars, the military men and the whole societies to stability and security of all the world, of their surroundings and of their own lives. Undoubtedly, such an event was the tsunami that caused the failure of the nuclear power plant in Fukushima. That catastrophe may be compared to the one in Hiroshima and the one in Chernobyl. In the present-day Europe similar threats are posed by the worn-out power plants in France (e.g. in Flamanville) and in Belgium (e.g. in Tihange). Especially the ones situated in the vicinity of a sea in extremely bad weather conditions may contaminate not only water resources but food as well in Europe. The radioactive Chernobyl fallout still penetrates the potential sources of animal feed and human food. Not without reason do ecologists and ordinary people, bearing in mind the past experiences, demand the dangerous nuclear power plants be closed down. The problem consists in the fact that it is difficult to replace a NPP and produce the same amount of energy in another way. The same threat is posed by hackers, who carry out terrorist attacks; when they take control of the systems of critical infrastructure it is a threat to the whole continent. The number of catastrophic phenomena, such as hurricanes, are on the increase, and so are the above mentioned threats; therefore we should ask ourselves whether we are really prepared to evacuate and secure people in case of a nuclear crisis. We have been taught a lesson by the past nuclear failures that in crises human behaviour is unpredictable and it may turn out that not everybody will be saved.
\end{abstract}

